\title{
Adaptation and Validation of the Malay Version of the Osteoarthritis Knee and Hip Quality of Life Questionnaire among Knee Osteoarthritis Patients
}

\author{
Azidah Abdul Kadir, ${ }^{1}$ Mohd Faizal Mohd Arif $\mathbb{D}^{\mathrm{D}}{ }^{1}$, Azlina Ishak (D), \\ Intan Idiana Hassan, ${ }^{2}$ and Norhayati Mohd Noor $\mathbb{1}^{1}$ \\ ${ }^{1}$ Department of Family Medicine, School of Medical Sciences, Universiti Sains Malaysia, Health Campus, \\ 16150 Kubang Kerian, Kelantan, Malaysia \\ ${ }^{2}$ Department of Nursing, School of Medical Sciences, Universiti Sains Malaysia, Health Campus, \\ 16150 Kubang Kerian, Kelantan, Malaysia
}

Correspondence should be addressed to Azlina Ishak; drzalinakk@usm.my

Received 25 October 2017; Revised 16 January 2018; Accepted 13 February 2018; Published 31 May 2018

Academic Editor: Alberto Raggi

Copyright (C) 2018 Azidah Abdul Kadir et al. This is an open access article distributed under the Creative Commons Attribution License, which permits unrestricted use, distribution, and reproduction in any medium, provided the original work is properly cited.

Objective. To adapt and validate the Malay version of Osteoarthritis Knee and Hip Quality of Life (OAKHQOL) questionnaire. Design. The OAKHQOL was adapted into Malay version using forward-backward translation methodology. It was then validated in a cross-sectional study of 191 patients with knee osteoarthritis (OA). Patients completed the OAKHQOL and Western Ontario and McMaster Universities Osteoarthritis Index (WOMAC) questionnaire. Confirmatory analysis, reliability analysis, and Pearson correlation test were performed. Results. The new five-factor model of 28 items demonstrated an acceptable level of goodness of fit (comparative fit index $=0.915$, Tucker-Lewis index $=0.905$, incremental fit index $=0.916$, chi-squared $/$ degree of freedom $=$ 1.953 , and root mean square error of approximation $=0.071$ ), signifying a fit model. The Cronbach's alpha value and the composite reliability of each construct ranged from 0.865 to 0.933 and 0.819 to 0.921 , respectively. The Pearson correlation coefficient between the OAKHQOL and the WOMAC showed adequate criterion validity. Known groups validity showed statistical difference in body mass index in physical activity, mental health, and pain construct. The pain domain was statistically different between the age groups. Conclusion. The Malay version OAKHQOL questionnaire is a valid and reliable instrument to assess health-related quality of life in knee OA patients.

\section{Introduction}

Osteoarthritis (OA) is the most common disease of joints in adults around the world $[1,2]$. Due to its chronicity in nature, it is the major cause of pain and disability. OA may affect not only physical functioning, but also mental health (anxiety and depression), sleep, work ability, interpersonal interactions, self-esteem, quality of life, sexuality, and participation $[3,4]$.

There are few validated instruments used in studies to assess health-related QOL in patients with OA specifically. The Medical Outcomes Study Short-Form 36 (SF36), which has been widely applied to assess QOL, is not disease-specific to $\mathrm{OA}$ and was found to have low response rate in population more than 65 years of age [5]. The Lequesne index and Western Ontario and McMaster Universities Osteoarthritis (WOMAC) questionnaire, which are more disease-specific, are able to measure only pain and function but not the other domains of QOL such as mental, social, and sexual domains $[6,7]$. It was suggested that the SF-36 and WOMAC should be used in combination [8]; however, they may still fail to capture specific QOL aspects related to hip or knee osteoarthritis. Knee Injury and Osteoarthritis Outcome Score (KOOS) is another questionnaire but its assessment is not 
limited to quality of life because it includes pain, other symptoms, activity of daily living, sports, and recreational activity measurements [9]. Thus, the Osteoarthritis Knee and Hip Quality of Life (OAKHQOL) scale questionnaire was developed and validated to measure the impact of specifically knee and hip osteoarthritis on the patient's QOL.

The OAKHQOL is a specific tool to measure QOL in knee and hip OA as it takes into account specific themes that are exclusive to the QOL of patients with knee and hip OA (social support, sleep, side effects of drugs, plans for the future, embarrassment to be seen by people, use of public transport, difficulty in moving after staying in the same position, and sexuality) [10]. It has 43 items which fall into five domains: physical activity, pain, mental health, social functioning, and social support. Evaluation of the OAKHQOL has shown the reliability of the five domains to be satisfactory (interclass correlation coefficients: $0.70-0.85$ ), the construct validity to be adequate (Spearman correlation coefficients: $0.43-0.75$ ), and the discrimination to be satisfactory [10].

Confirmatory factor analysis (CFA) is a theory-testing model as opposed to exploratory factor analysis (EFA) which is a theory-generating method [11]. CFA is a type of structural equation modeling (SEM) that specifically deals with measurement models, that is, the relationships between observed measures or indicators and latent variables or factors $[12,13]$. It is powerful because it provides explicit hypothesis testing for factor analytic problems.

Assessing the QOL among knee OA patients is important to ensure holistic care for the patient. Despite this, the reliability and validity of the OAKHQOL in the Malaysian context have not been established. The need for a validated questionnaire suitable to the local population based on the language is very important as it is more accurate to illustrate the real impact of the disease on the patient's QOL. Hence, this study aimed to determine the psychometric properties of the Malay version of the OAKHQOL among knee OA patients.

\section{Materials and Methods}

A cross-sectional study was conducted among 191 patients diagnosed with knee OA between February and August 2014 at the Outpatient Clinic, Universiti Sains Malaysia Hospital, a tertiary teaching hospital in Malaysia. A total of 210 patients were invited, and only 191 patients fulfilled the inclusion and exclusion criteria and were recruited in the study, which give the response rate of $90 \%$. Patients with unilateral or bilateral knee osteoarthritis diagnosed according to the clinical and radiological criteria of the American College of Rheumatology (knee pain and radiographic osteophytes plus at least one of three symptoms/signs), aged more than 50 years, who experienced morning stiffness of less than 30 minutes and crepitus on active motion, and who were able to read in the Malay language were included.
Convenience sampling was applied, and written informed consent was taken. Patients were asked to fill out the Malay version OAKHQOL (Table 7) and the validated Malay Version WOMAC. Sociodemographic data (age, gender, education, and race) and knee OA history were taken. Body mass index (BMI) measurements and weight-bearing anteriorposterior view X-rays of both knees were taken. The participants took about 15 minutes to complete both questionnaires. They also did not have to pay for their participation in the study.

Sample size was determined based on Hair et al. (2010). The minimum sample size required for five or less constructs was 100 samples [14].

2.1. OAKHQOL Questionnaire. This questionnaire was developed by Rat et al. to assess quality of life in knee and hip OA patients $[10,15]$, specifically to assess health-related quality of life (HRQOL) [10]. The concept of this questionnaire was based on the World Health Organization (WHO) definition of QOL. This is a self-administered questionnaire. The original questionnaire was developed in French and later in English [15]. It was shown to capture patients' perceptions of their disease, and it possesses the necessary psychometric properties of validity and reliability for use in clinical trials and observational studies $[10,15]$.

In the original validation study, four factors were identified in the exploratory factor analysis based on scree plot and Eigen values. These factors were physical activities (19 items), mental health (14 items), social support (four items), and social functioning (three items). The pain factor (four items) was found to have loaded on the physical and mental health factors. However, based on expert opinions, the pain factor was included as an individual dimension. Therefore, the final English version of OAKHQOL consists of 43 items divided into five dimensions: physical activity, mental health, pain, social support, and social functioning as well as three additional items [10]. The three additional items are relationship, sexual activity, and professional life. The five dimensions (40 items) (Table 8) and three additional items are intended to be used separately. The three additional items are independent items and were not included in the analysis. Each item in the five dimensions is measured on a numerical rating scale from 0 to 10 . The final scores were the mean of scores of all the items in respective domains that ranged between 0 to 10 [10].

2.2. Adaptation of the OAKHQOL Questionnaire. Forward and backward translation was carried out by a group of panelists consisting of family medicine specialists, physicians, linguists, and bilingual laymen. Modifications were made, and content validity was checked. The revised version was tested on 20 patients for face validity. These patients were excluded from the psychometric analysis.

2.3. WOMAC. WOMAC is a disease-specific, self-administered health status measure that is widely used to assess the symptoms and physical disability for people with hip and/or knee OA $[16,17]$. It is widely used in OA research especially 
to evaluate clinical outcome measures as a result of treatment intervention [18]. The WOMAC measures total pain score, total stiffness score, and total physical functioning score. The original index consists of 24 questions (five questions for pain, two questions for stiffness, and 17 questions for physical function). It has been validated in Bahasa, Malaysia [16]. This questionnaire is available in a Likert version rated on an ordinal scale of 0 to 4 and also as a visual analog scale (VAS) [16]. In this study, a VAS version was used.

2.4. Statistical Analysis. Confirmatory factor analysis (CFA), reliability analysis, and Pearson correlation test were performed to assess the psychometric properties using SPSS version 22.0 and Analysis of Moment Structure (AMOS) software version 21.0. On preliminary data screening, cases with incomplete response were removed from data. Further assessment of normality and outliers was performed on the factor scores based on the critical ratio (i.e., for skewness and kurtosis to their standard error) and the Mahalanobis distance. Mahalanobis distance was used to identify the outliers by using AMOS software. It computes and tabulates the distance of every data from the center of all data distribution [19].

The CFA was performed to examine the goodness of fit indices of the Malay OAKHQOL latent construct. Construct validity examines the degree to which a scale measures what it intends to measure [20]. Construct validity is achieved if the goodness of fit indices signify a model fit [20].

The measurement of the model fit was checked with several goodness of fit indicators: comparative fit index (CFI), Tucker-Lewis index (TLI), incremental fit index (IFI), chisquared/degree of freedom, and root mean square error of approximation (RMSEA) [12, 13, 21]. For approximate fit index, a value of more than 0.9 was taken for CFI, IFI, and TLI $[21,22]$. Chi-squared/degree of freedom of less than 3 and RMSEA value of less than 0.08 were taken as indicators of an acceptable level $[12,13,19]$.

In addition to the overall evaluation of goodness of fit, the standardized factor loading (standardized regression weight) modification indices (MI) and squared multiple correlation $\left(R^{2}\right)$ were used as indicators to select which items should be removed in the model $[12,13]$. MI suggested correlations between variables. A high MI value indicates redundancy in a pair of variables $[12,13]$. Discriminant validity is also assessed by obtaining correlation values between the constructs. A correlation of more than 0.85 between constructs is considered to indicate poor discriminant validity $[12,13]$.

Reliability analysis was measured using Cronbach's alpha coefficient, composite reliability (CR), and average variance extracted (AVE). Reliability refers to the accuracy and precision of the measurement procedure. Cronbach's alpha coefficient was measured using SPSS. Both CR and AVE were derived from CFA analysis and manually calculated based on published formula $[19,23]$. A Cronbach's alpha coefficient value of more than 0.7 and a CR equal to or greater than 0.6 represent a measure of satisfactory internal consistency [19, $24,25]$. AVE is the average percentage of variation explained by the variables in the construct or domain. The acceptable value for it was taken as more than 0.5 [19]. In this study, the test-retest reliability was not done due to time constraint and limited budget.

The Pearson correlation test was performed to assess the criterion validity of the OAKHQOL. The test was done between the pain construct of the OAKHQOL and the pain construct of the WOMAC, as well as between the physical construct of the OAKHQOL and the functional construct of the WOMAC. The correlation coefficient of more than 0.5 but less than 0.8 was considered to be a good correlation [26].

Known group validity is a method to support construct validity of a questionnaire. The method will evaluate the questionnaire ability to discriminate between the two groups known to differ on the variable of interest [27]. In this study, known group validity was assessed through gender, BMI, age groups of the patients, and Kellgren-Lawrence grading of the knee radiograph. We hypothesized that females, those aged more than 60 years [28], those having a BMI greater than $25 \mathrm{~kg} / \mathrm{m}^{2}$, and those with more severe radiographic grading would have significant differences [10]. An independent $t$-test was used to analyze for gender, BMI, and age groups of the patients. One-way ANOVA test was used to analyze radiographic grading based on Kellgren-Lawrence classification. In the analysis for known group validity, the score for each domain was normalized to $0-100$.

\section{Results}

3.1. Translation and Cultural Adaptation. We found that all the items in the Malay version questionnaire are relevant and appropriate to the Malaysian population. All the items were found to be acceptable, clear, and easy to understand in the face validity.

3.2. Psychometric Properties. A total of 191 patients participated in the study. The sociodemographic and knee OA disease characteristics of the participants are shown in Table 1. The mean age was 57.8 (6.8) years and the majority were female. The Kellgren-Lawrence classification ranged from grade 0 to 4 .

3.3. Descriptive Statistics of the Items. The items in the five constructs of OAKHQOL had missing data ranging from 0 to 3 values $(0 \%-1.5 \%)$. However, the individual items concerning professional life, relationships, and sexual activities had 10 to 13 missing values. The missing values were replaced with the mean scores for the domain during the CFA. Normality assessment was done for the 40 items in the five constructs using histogram, box-plot, and measurement of skewness, which showed normal distribution. The absolute and percentage frequencies of the score for all the items were calculated and illustrated in Table 2. 
TABLE 1: Sociodemographic and clinical characteristics of knee OA patients.

\begin{tabular}{|c|c|c|c|}
\hline Variables & Mean & (SD) & $N(\%)$ \\
\hline Age (year) & 57.8 & 6.8 & \\
\hline \multicolumn{4}{|l|}{ Gender: } \\
\hline Male & & & $63(33)$ \\
\hline Female & & & $128(67)$ \\
\hline \multicolumn{4}{|l|}{ Education: } \\
\hline Primary & & & $30(15.7)$ \\
\hline Secondary & & & $132(69.1)$ \\
\hline Tertiary & & & $29(15.2)$ \\
\hline \multicolumn{4}{|l|}{ Race: } \\
\hline Malay & & & $186(97.4)$ \\
\hline Chinese & & & $5(2.6)$ \\
\hline $\operatorname{BMI}\left(\mathrm{kg} / \mathrm{m}^{2}\right)$ & 28.5 & 5.1 & \\
\hline Duration of knee OA (year) & 3.7 & 3.7 & \\
\hline \multicolumn{4}{|l|}{ Knee joint affected } \\
\hline Left & & & $43(22.5)$ \\
\hline Right & & & $34(17.8)$ \\
\hline Both & & & $114(59.7)$ \\
\hline \multicolumn{4}{|c|}{ Kellgren-Lawrence classification: } \\
\hline 0 & & & $59(30.9)$ \\
\hline 1 & & & $68(35.6)$ \\
\hline 2 & & & $33(17.3)$ \\
\hline 3 & & & $27(14.1)$ \\
\hline 4 & & & $4(2.1)$ \\
\hline
\end{tabular}

3.4. Confirmatory Analysis. Confirmatory factor analysis was performed with one-step strategy. Confirmatory analysis showed that the original five-factor model of the OAKHQOL (40 items) was not fit (Table 3). Five items (py25, m36, m37, $\mathrm{m} 38$, and $\mathrm{m} 16$ ) were removed one by one due to low factor loadings, as shown in Model A. Eight items were set as free parameter estimates, one pair at a time (py1-py2, py7-py8, py4-py5, and pn34-pn33), based on high MI (greater than 15) as shown in Model C. Further item deletion was done based on MI and factor loadings (py3, py9, m29, py24, sp39, py14, and py13) until the final model, which consists of a five factors with 28 items, signified a model fit (Table 3 ). The final model consists of five constructs: physical activity (10 items), mental health (eight items), social functioning (three items), social support (three items), and pain (four items). Six items in the physical activity, five items in the mental health, and one item in the social support were removed. The goodness of fit indices indicated that the model had a good construct $(\mathrm{CFI}=0.915$, TLI $=0.905$, IFI $=0.916$, chisquared/degree of freedom $=1.953$, and RMSEA $=0.071$ ) (Table 3).

The initial model before fit was shown in Figure 1. The correlation between factors was illustrated in Figure 2. The standardized factor loadings were from 0.5 to 0.9 , indicating that all items contributed highly to the construct measures. The MI values were less than 10 , and the correlation between each pair of latent constructs was less than 0.85 , which is acceptable (Figure 2) [19].

3.5. Reliability. The reliability analysis showed that the Cronbach's alpha coefficient value for each construct was greater than 0.7 (Table 4). The CR and AVE of each construct also showed that the final construct had a good measure of reliability. The result was achieved by using one-step estimation strategy.

Table 5 shows the Pearson's correlation coefficients between the physical activity construct of the OAKHQOL and the functional construct of the WOMAC $(r=0.72)$ and between the pain construct of the OAKHQOL and pain construct of the WOMAC $(r=0.55)$. These results indicated that the OAKHQOL had acceptable criterion validity.

3.6. Known Group Validity. The results for the known group validity of the OAKHQOL are shown in Table 6. We found significant differences among the BMI groups (BMI $\leq 25 \mathrm{~kg} / \mathrm{m}^{2}$ and $\left.>25 \mathrm{~kg} / \mathrm{m}^{2}\right)$ in the physical activity $(p=$ $0.009)$, mental $(p=0.040)$, and pain domains $(p=0.009)$. We also found significant differences among the groups based on OA severity according to radiographic grading in the physical activity $(p=0.002)$ and pain domains $(p=$ 0.043 ). Thus, groups who had greater disease severity based on radiography had worse scores. The scores of the pain domain for the age groups (age $\leq 60$ years compared to those 
TABLE 2: Absolute and percentage frequencies of score for all items.

\begin{tabular}{|c|c|c|c|c|c|c|c|c|c|c|c|c|c|}
\hline \multicolumn{2}{|c|}{ Score item } & 0 & 1 & 2 & 3 & 4 & 5 & 6 & 7 & 8 & 9 & 10 & Total \\
\hline \multirow{2}{*}{ Py1 } & Freq & 11 & 24 & 20 & 24 & 26 & 38 & 12 & 20 & 7 & 3 & 6 & 191 \\
\hline & $\%$ & 5.8 & 12.6 & 10.5 & 12.6 & 13.6 & 19.9 & 6.3 & 10.5 & 3.7 & 1.6 & 3.1 & 100 \\
\hline \multirow{2}{*}{ Py 2} & Freq & 9 & 14 & 25 & 23 & 15 & 37 & 17 & 21 & 13 & 10 & 7 & 191 \\
\hline & $\%$ & 4.7 & 7.3 & 13.1 & 12.0 & 7.9 & 19.4 & 8.9 & 11.0 & 6.8 & 5.2 & 3.7 & 100 \\
\hline \multirow{2}{*}{ Рy3 } & Freq & 11 & 15 & 16 & 12 & 23 & 32 & 25 & 19 & 16 & 15 & 7 & 191 \\
\hline & $\%$ & 5.8 & 7.9 & 8.4 & 6.3 & 12.0 & 16.8 & 13.1 & 9.9 & 8.4 & 7.9 & 3.7 & 100 \\
\hline \multirow{2}{*}{ Py 4} & Freq & 8 & 10 & 11 & 21 & 22 & 45 & 20 & 23 & 15 & 12 & 4 & 191 \\
\hline & $\%$ & 4.2 & 5.2 & 5.8 & 11.0 & 11.5 & 23.6 & 10.5 & 12.0 & 7.9 & 6.3 & 2.1 & 100 \\
\hline \multirow{2}{*}{ Py5 } & Freq & 7 & 8 & 12 & 15 & 20 & 23 & 32 & 33 & 20 & 15 & 6 & 191 \\
\hline & $\%$ & 3.7 & 4.2 & 6.3 & 7.9 & 10.5 & 12.0 & 16.8 & 17.3 & 10.5 & 7.9 & 3.1 & 100 \\
\hline \multirow{2}{*}{ Py6 } & Freq & 49 & 32 & 25 & 23 & 14 & 22 & 9 & 7 & 4 & 4 & 2 & 191 \\
\hline & $\%$ & 25.7 & 16.8 & 13.1 & 12.0 & 7.3 & 11.5 & 4.7 & 3.7 & 2.1 & 2.1 & 1.0 & 100 \\
\hline \multirow{2}{*}{ Py7 } & Freq & 35 & 22 & 21 & 16 & 20 & 26 & 22 & 11 & 10 & 7 & 1 & 191 \\
\hline & $\%$ & 18.3 & 11.5 & 11.0 & 8.4 & 10.5 & 13.6 & 11.5 & 5.8 & 5.2 & 3.7 & 0.5 & 100 \\
\hline \multirow{2}{*}{ Py8 } & Freq & 35 & 24 & 18 & 16 & 14 & 28 & 16 & 11 & 15 & 9 & 5 & 191 \\
\hline & $\%$ & 18.3 & 12.6 & 9.4 & 8.4 & 7.3 & 14.7 & 8.4 & 5.8 & 7.9 & 4.7 & 2.6 & 100 \\
\hline \multirow{2}{*}{ Py9 } & Freq & 2 & 13 & 17 & 11 & 20 & 32 & 28 & 21 & 17 & 23 & 7 & 191 \\
\hline & $\%$ & 1.0 & 6.8 & 8.9 & 5.8 & 10.5 & 16.8 & 14.7 & 11.0 & 8.9 & 12.0 & 3.7 & 100 \\
\hline \multirow{2}{*}{ Py10 } & Freq & 18 & 14 & 19 & 16 & 17 & 36 & 27 & 16 & 12 & 10 & 6 & 191 \\
\hline & $\%$ & 9.4 & 7.3 & 9.9 & 8.4 & 8.9 & 18.8 & 14.1 & 8.4 & 6.3 & 5.2 & 3.1 & 100 \\
\hline \multirow{2}{*}{ Pyll } & Freq & 33 & 15 & 14 & 14 & 31 & 25 & 14 & 12 & 12 & 7 & 4 & 191 \\
\hline & $\%$ & 17.3 & 7.9 & 7.3 & 7.3 & 16.2 & 13.1 & 7.3 & 6.3 & 6.3 & 3.7 & 7.3 & 100 \\
\hline \multirow{2}{*}{ Py13 } & Freq & 45 & 24 & 23 & 18 & 17 & 27 & 17 & 13 & 2 & 2 & 3 & 191 \\
\hline & $\%$ & 23.6 & 12.6 & 12.0 & 9.4 & 8.9 & 14.1 & 8.9 & 6.8 & 1.1 & 1.1 & 1.6 & 100 \\
\hline \multirow{2}{*}{ Py14 } & Freq & 31 & 17 & 22 & 20 & 21 & 32 & 16 & 15 & 11 & 3 & 3 & 191 \\
\hline & $\%$ & 16.2 & 8.9 & 11.5 & 10.5 & 11.0 & 16.8 & 8.4 & 7.9 & 5.8 & 1.6 & 1.6 & 100 \\
\hline \multirow{2}{*}{ M15 } & Freq & 25 & 19 & 21 & 19 & 22 & 29 & 23 & 13 & 8 & 9 & 3 & 191 \\
\hline & $\%$ & 13.1 & 9.9 & 11.0 & 9.9 & 11.5 & 15.2 & 12.0 & 6.8 & 4.2 & 4.7 & 1.6 & 100 \\
\hline \multirow{2}{*}{ M16 } & Freq & 20 & 21 & 19 & 18 & 14 & 27 & 25 & 20 & 13 & 7 & 7 & 191 \\
\hline & $\%$ & 10.5 & 11.0 & 9.9 & 9.4 & 7.3 & 14.1 & 13.1 & 10.5 & 6.8 & 3.7 & 3.7 & 100 \\
\hline M17 & Freq & 18 & 26 & 21 & 16 & 17 & 26 & 20 & 18 & 16 & 8 & 5 & 191 \\
\hline 1011 & $\%$ & 9.4 & 13.6 & 11.0 & 8.4 & 8.9 & 13.6 & 10.5 & 9.4 & 8.4 & 4.2 & 2.6 & 100 \\
\hline M18 & Freq & 40 & 20 & 18 & 20 & 17 & 22 & 16 & 12 & 15 & 7 & 4 & 191 \\
\hline & $\%$ & 20.9 & 10.5 & 9.4 & 10.5 & 8.9 & 11.5 & 8.4 & 6.3 & 7.9 & 3.7 & 2.1 & 100 \\
\hline M19 & Freq & 36 & 28 & 18 & 15 & 18 & 29 & 17 & 12 & 8 & 7 & 3 & 191 \\
\hline $1 \mathrm{VH1}$ & $\%$ & 18.8 & 14.7 & 9.4 & 7.9 & 9.4 & 15.2 & 8.9 & 6.3 & 4.2 & 3.7 & 1.6 & 100 \\
\hline M20 & Freq & 33 & 27 & 22 & 17 & 16 & 34 & 15 & 9 & 6 & 9 & 3 & 191 \\
\hline & $\%$ & 17.3 & 14.1 & 11.5 & 8.9 & 8.4 & 17.8 & 7.9 & 4.7 & 3.1 & 4.7 & 1.6 & 100 \\
\hline M21 & Freq & 51 & 27 & 13 & 22 & 7 & 29 & 11 & 13 & 9 & 7 & 2 & 191 \\
\hline & $\%$ & 26.7 & 14.1 & 6.8 & 11.5 & 3.7 & 15.2 & 5.8 & 6.8 & 4.7 & 3.7 & 1.0 & 100 \\
\hline Py24 & Freq & 6 & 11 & 19 & 19 & 18 & 27 & 27 & 19 & 22 & 15 & 8 & 191 \\
\hline $1 y z 4$ & $\%$ & 3.1 & 5.8 & 9.9 & 9.9 & 9.4 & 14.1 & 14.1 & 9.9 & 11.5 & 7.9 & 4.2 & 100 \\
\hline Py25 & Freq & 100 & 21 & 16 & 10 & 6 & 14 & 4 & 5 & 3 & 4 & 8 & 191 \\
\hline & $\%$ & 52.4 & 11.0 & 8.4 & 5.2 & 3.1 & 7.3 & 2.1 & 2.6 & 1.6 & 2.1 & 4.2 & 100 \\
\hline $\mathrm{Pn} 26$ & Freq & 9 & 16 & 23 & 24 & 20 & 30 & 13 & 21 & 15 & 12 & 8 & 191 \\
\hline 11120 & $\%$ & 4.7 & 8.4 & 12.0 & 12.6 & 10.5 & 15.7 & 6.8 & 11.0 & 7.9 & 6.3 & 4.2 & 100 \\
\hline $\mathrm{Pn} 27$ & Freq & 20 & 14 & 25 & 25 & 16 & 31 & 18 & 16 & 14 & 6 & 6 & 191 \\
\hline & $\%$ & 10.5 & 7.3 & 13.1 & 13.1 & 8.4 & 16.2 & 9.4 & 8.4 & 7.3 & 3.1 & 3.1 & 100 \\
\hline Py28 & Freq & 46 & 31 & 15 & 18 & 12 & 27 & 13 & 12 & 7 & 7 & 3 & 191 \\
\hline Рyzo & $\%$ & 24.1 & 16.2 & 7.9 & 9.4 & 6.3 & 14.1 & 6.8 & 6.3 & 3.7 & 3.7 & 1.6 & 100 \\
\hline M29 & Freq & 39 & 24 & 18 & 17 & 18 & 30 & 22 & 4 & 9 & 8 & 2 & 191 \\
\hline & $\%$ & 20.4 & 12.6 & 9.4 & 8.9 & 9.4 & 15.7 & 11.5 & 2.1 & 4.7 & 4.2 & 1.0 & 100 \\
\hline
\end{tabular}


TABLE 2: Continued.

\begin{tabular}{|c|c|c|c|c|c|c|c|c|c|c|c|c|c|}
\hline \multicolumn{2}{|c|}{ Score item } & 0 & 1 & 2 & 3 & 4 & 5 & 6 & 7 & 8 & 9 & 10 & Total \\
\hline \multirow{2}{*}{ Sf30 } & Freq & 20 & 8 & 24 & 17 & 14 & 34 & 15 & 8 & 14 & 16 & 21 & 191 \\
\hline & $\%$ & 10.5 & 4.2 & 12.6 & 8.9 & 7.3 & 17.8 & 7.9 & 4.2 & 7.3 & 8.4 & 11.0 & 100 \\
\hline \multirow{2}{*}{ Sf31 } & Freq & 17 & 12 & 18 & 20 & 14 & 36 & 18 & 6 & 7 & 19 & 24 & 191 \\
\hline & $\%$ & 8.9 & 6.3 & 9.4 & 10.5 & 7.3 & 18.8 & 9.4 & 3.1 & 3.7 & 9.9 & 12.6 & 100 \\
\hline \multirow{2}{*}{ Sf32 } & Freq & 12 & 12 & 12 & 19 & 24 & 28 & 16 & 9 & 15 & 18 & 26 & 191 \\
\hline & $\%$ & 6.3 & 6.3 & 6.3 & 9.9 & 12.6 & 14.7 & 8.4 & 4.7 & 7.9 & 9.4 & 13.6 & 100 \\
\hline \multirow{2}{*}{ Pn33 } & Freq & 44 & 24 & 21 & 13 & 12 & 32 & 16 & 9 & 14 & 4 & 2 & 191 \\
\hline & $\%$ & 23.0 & 12.6 & 11.0 & 6.8 & 6.3 & 16.8 & 8.4 & 4.7 & 7.3 & 2.1 & 1.0 & 100 \\
\hline \multirow{2}{*}{ Pn34 } & Freq & 51 & 24 & 21 & 11 & 17 & 27 & 13 & 10 & 13 & 3 & 1 & 191 \\
\hline & $\%$ & 26.7 & 12.6 & 11.0 & 5.8 & 8.9 & 14.1 & 6.8 & 5.2 & 6.8 & 1.6 & 0.5 & 100 \\
\hline \multirow{2}{*}{ M35 } & Freq & 19 & 33 & 30 & 17 & 13 & 37 & 11 & 12 & 8 & 6 & 5 & 191 \\
\hline & $\%$ & 9.9 & 17.3 & 15.7 & 8.9 & 6.8 & 19.4 & 5.8 & 6.3 & 4.2 & 3.1 & 2.6 & 100 \\
\hline \multirow{2}{*}{ M36 } & Freq & 40 & 29 & 23 & 17 & 20 & 30 & 11 & 7 & 9 & 4 & 1 & 191 \\
\hline & $\%$ & 20.9 & 15.2 & 12.0 & 8.9 & 10.5 & 15.7 & 5.8 & 3.7 & 4.7 & 2.1 & 0.5 & 100 \\
\hline \multirow{2}{*}{ M37 } & Freq & 68 & 29 & 19 & 15 & 15 & 26 & 7 & 4 & 3 & 5 & 0 & 191 \\
\hline & $\%$ & 35.6 & 15.2 & 9.9 & 7.9 & 7.9 & 13.6 & 3.7 & 2.1 & 1.6 & 2.6 & 0 & 100 \\
\hline \multirow{2}{*}{ M38 } & Freq & 37 & 28 & 20 & 18 & 17 & 34 & 12 & 9 & 9 & 6 & 1 & 191 \\
\hline & $\%$ & 19.4 & 14.7 & 10.5 & 9.4 & 8.9 & 17.8 & 6.3 & 4.7 & 4.7 & 3.1 & 5 & 100 \\
\hline \multirow{2}{*}{ Sp39 } & Freq & 9 & 11 & 12 & 16 & 14 & 23 & 17 & 23 & 16 & 16 & 34 & 191 \\
\hline & $\%$ & 4.7 & 5.8 & 6.3 & 8.4 & 7.3 & 12.0 & 8.9 & 12.0 & 8.4 & 8.4 & 17.8 & 100 \\
\hline \multirow{2}{*}{ Sp40 } & Freq & 9 & 9 & 15 & 11 & 13 & 39 & 14 & 12 & 26 & 21 & 22 & 191 \\
\hline & $\%$ & 4.7 & 4.7 & 7.9 & 5.8 & 6.8 & 20.4 & 7.3 & 6.3 & 13.6 & 11.0 & 11.5 & 100 \\
\hline \multirow{2}{*}{ M41 } & Freq & 45 & 24 & 22 & 17 & 11 & 37 & 13 & 6 & 6 & 7 & 3 & 191 \\
\hline & $\%$ & 23.6 & 12.6 & 11.5 & 8.9 & 5.8 & 19.4 & 6.8 & 3.1 & 3.1 & 3.7 & 1.6 & 100 \\
\hline \multirow{2}{*}{$\mathrm{sp} 42$} & Freq & 10 & 6 & 16 & 12 & 9 & 23 & 13 & 16 & 14 & 20 & 52 & 191 \\
\hline & $\%$ & 5.2 & 3.1 & 8.4 & 6.3 & 4.7 & 12.0 & 6.8 & 8.4 & 7.3 & 10.5 & 27.2 & 100 \\
\hline \multirow{2}{*}{ sp43 } & Freq & 11 & 10 & 13 & 15 & 12 & 28 & 16 & 15 & 19 & 18 & 34 & 191 \\
\hline & $\%$ & 5.8 & 5.2 & 6.8 & 7.9 & 6.3 & 14.7 & 8.4 & 7.9 & 9.9 & 9.4 & 17.8 & 100 \\
\hline
\end{tabular}

Py: physical activity; m: mental health; pn: pain; sf: social functioning; sp: social support.

TABLE 3: Fitness level of models.

\begin{tabular}{|c|c|c|c|c|c|c|}
\hline 5-factor model & RMSEA & CFI & IFI & TLI & $\begin{array}{c}\text { Chi } \\
\text { Square/df }\end{array}$ & Actions taken \\
\hline $\begin{array}{l}\text { Original: } \\
(40 \text { item })\end{array}$ & 0.100 & 0.770 & 0.772 & 0.754 & 2.908 & \\
\hline \multirow[t]{2}{*}{$\begin{array}{l}\text { Model A: } \\
35 \text { items }\end{array}$} & \multirow[t]{2}{*}{0.094} & \multirow[t]{2}{*}{0.826} & \multirow[t]{2}{*}{0.827} & \multirow[t]{2}{*}{0.811} & \multirow[t]{2}{*}{2.680} & $\begin{array}{c}\text { Delete } \\
\text { py25, m36, m37, } \\
\text { m38 }\end{array}$ \\
\hline & & & & & & $\mathrm{m} 16$ \\
\hline \multirow{5}{*}{$\begin{array}{l}\text { Model B: } \\
35 \text { items }\end{array}$} & \multirow{5}{*}{0.094} & \multirow{5}{*}{0.843} & \multirow{5}{*}{0.844} & \multirow{5}{*}{0.829} & \multirow{5}{*}{2.680} & $\begin{array}{c}\text { Correlate between } \\
\text { the errors }\end{array}$ \\
\hline & & & & & & py7-py8 \\
\hline & & & & & & py4-py5 \\
\hline & & & & & & py1-py2 \\
\hline & & & & & & pn33-pn34 \\
\hline $\begin{array}{l}\text { Model C } \\
30 \text { items }\end{array}$ & 0.090 & 0.901 & 0.902 & 0.890 & 2.061 & $\begin{array}{l}\text { Delete: py3, py9, } \\
\text { m29, py24, sp } 39\end{array}$ \\
\hline $\begin{array}{l}\text { Final model: } \\
28 \text { items }\end{array}$ & 0.071 & 0.915 & 0.916 & 0.905 & 1.953 & $\begin{array}{l}\text { Delete pyl4 and } \\
\text { pyl3 }\end{array}$ \\
\hline
\end{tabular}

CFI: comparative fit index; TLI: Tucker-Lewis index; IFI: incremental fit index; RMSEA: root mean squared error of approximation. 


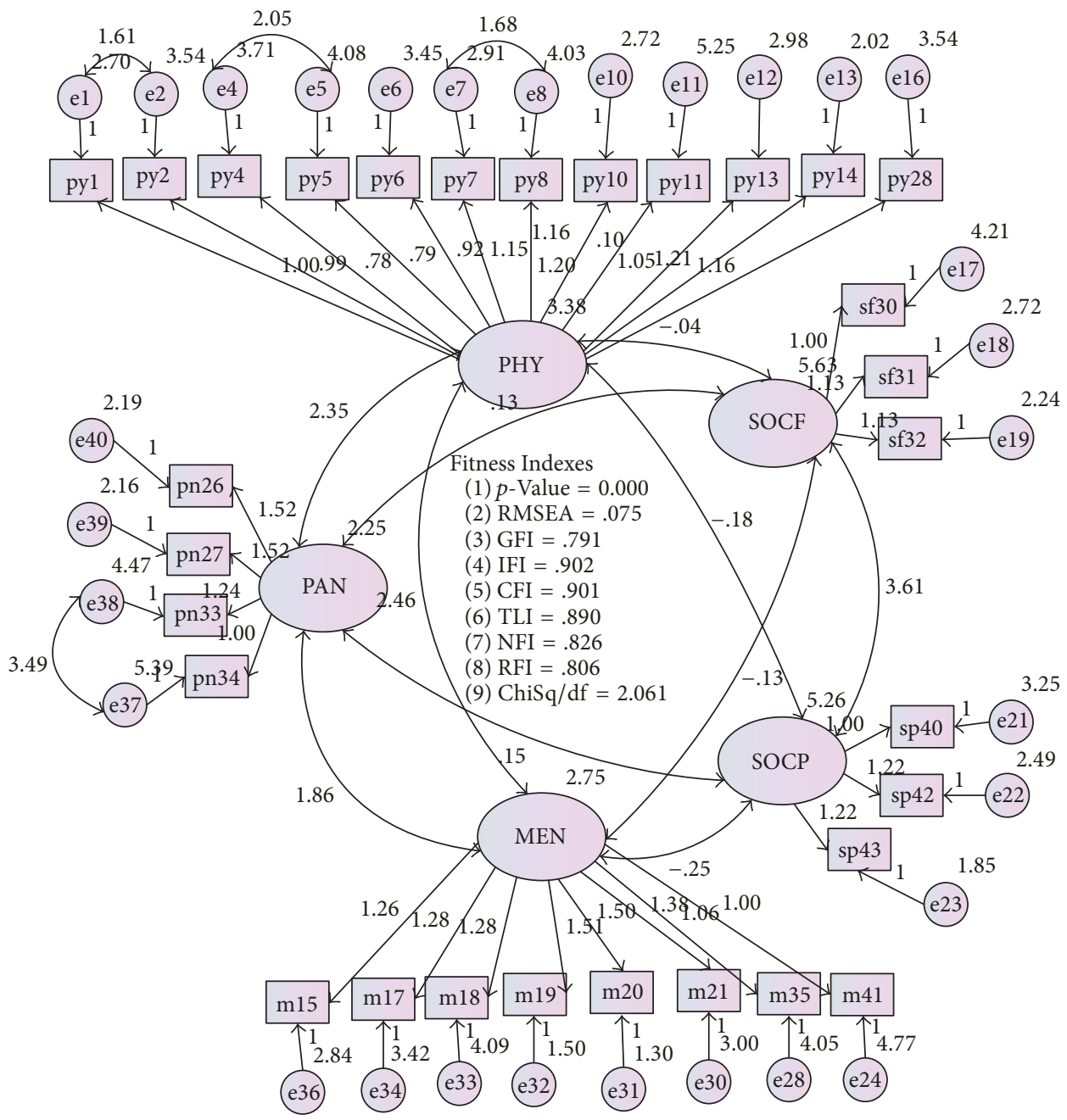

Figure 1: The initial AMOS graphic shows the goodness of fit indexes, respective path coefficient, factor loading, and R2. PHY: physical activity, SOCF: social functioning, SOCP: social support, MEN: mental health, PAN: pain.

age $>60$ years) were also significant. There were no differences observed for the social support and social function domains.

\section{Discussion}

Recently, validated health-related quality of life that accurately reflects a patient's experience with respect to specific disease has been an important outcome recommended for interventional study. Health-related quality of life is a broad concept representing individual responses to physical, mental, and social effects on daily living. Therefore, the need to assess conceptual relevance and psychometric properties in various cultures or countries is increasing [15].

The present study indicated that the shortened Malay version of the OAKHQOL had good validity and reliability and is culturally acceptable. EFA of the original OAKHQOL using principle component analysis with orthogonal varimax rotation revealed four factors: physical activities, mental health, social support, and social functioning with the pain factor as an individual dimension [10, 15]. The OAKHQOL has also been validated in Spanish and Persian [2, 29]. However, to our knowledge, this is the first study that used confirmatory analysis in the validation analysis. CFA is used to verify the factor structure of a measurement instrument. CFA has become more commonly used for construct validation and to provide evidence for convergent and discriminant validity of the theoretical construct [30]. Furthermore, CFA is a theory-testing model and it starts with a hypothesis prior to the analysis which is based on strong theoretical and/or empirical foundation [31]. On the other hand, EFA is used to explore the possible underlying factor structure of a measurement instrument [32].

The panel in this study decided to keep the original fivefactor model in the initial analysis, although the EFA of the original study did not support this. EFA of the original study was done in other language; thus the result was different. The decision to keep the pain construct in the final model was 


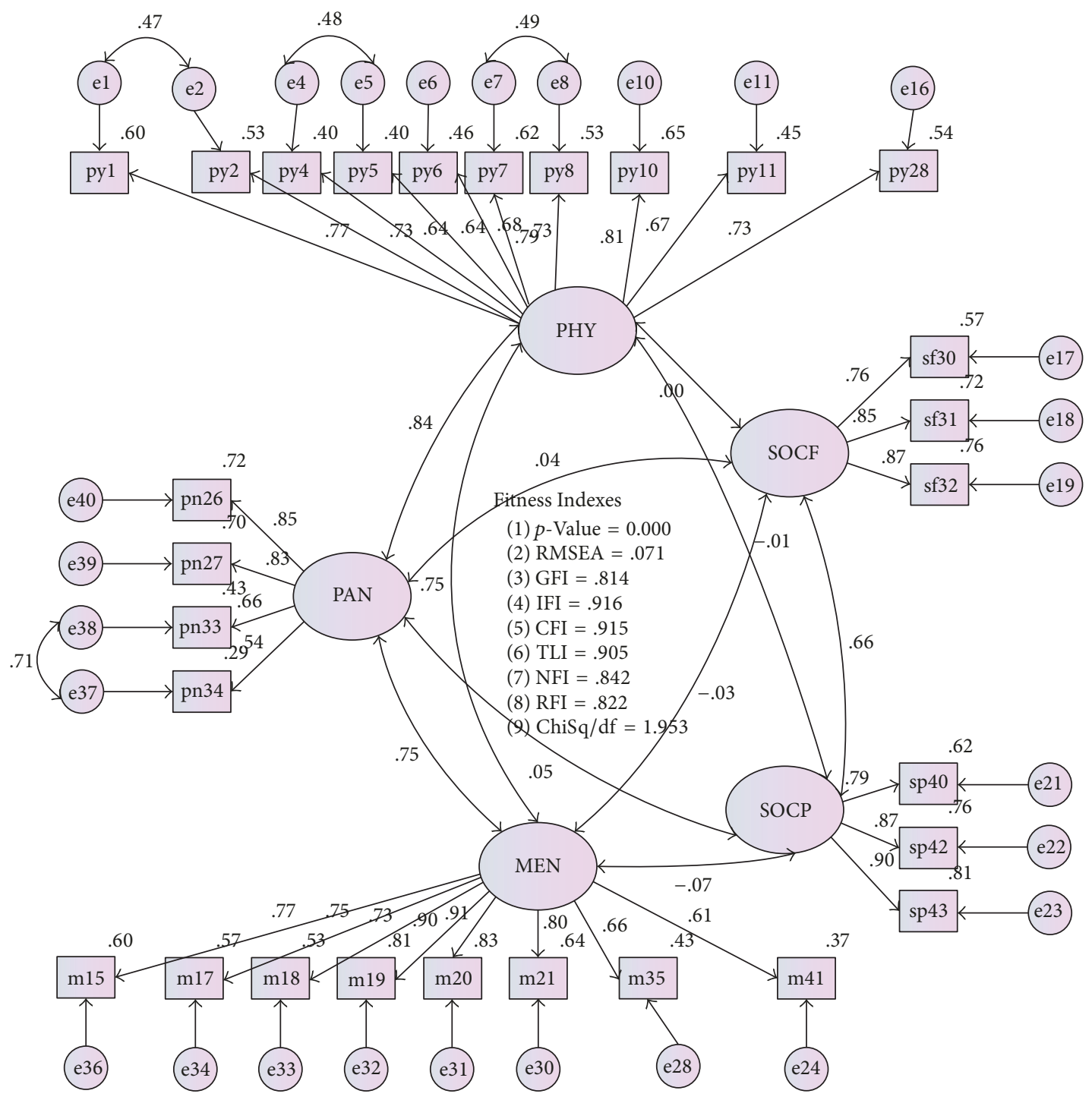

FIgUre 2: The AMOS graphic shows the goodness of fit indexes, respective path coefficient, factor loading, and R2. The final model shows 5 constructs and 28 items. PHY: physical activity, SOCF: social functioning, SOCP: social support, MEN: mental health, PAN: pain.

made because we found the pain factor to be an important domain that is also available in and consistent with other health-related QOL for OA measures and the items were also culturally acceptable $[16,17]$.

We made the decision to remove six items from the physical activity construct (py3, py9, py13, py14, py24, and py25), five items in the mental health construct (m16, m29, $\mathrm{m} 36, \mathrm{~m} 37$, and $\mathrm{m} 38$ ), and one item in the social support construct (sp39) because other items in the construct reflected similar functions. Most of the items were removed because of significant overlapping (high modification indices) and lack of discrimination within the items. Removal of these items was shown to improve the fit indices of the model, indicating that perhaps they poorly represented the construct being measured. However, the panel of this study had also revisited and reviewed the items before they were removed because they might represent important and meaningful construct as mentioned in a previous validation study.
The reliability analysis showed that internal consistency of the Malay version OAKHQOL was acceptable. Other than that, the CR and AVE for each construct were also acceptable, indicating that they had good levels of internal consistency. As for the criterion validity, the analysis showed that the physical and pain constructs of the Malay version of OAKHQOL had good correlations with the functional and pain constructs of the WOMAC. In Malay version of OAKHQOL, physical activity construct has 10 items whereas WOMAC has 17 items in functional construct [16]. In physical activity and functional construct of both questionnaires, daily activities such as difficulty in walking, bending, going up and down the stairs, and getting in and out of a car or a bus were assessed. Physical activity on self-care such as taking bath, getting dressed, and cutting toe-nails was assessed in OAKHQOL, whereas WOMAC assessed other aspects of daily activities such as difficulty in sitting, standing, lying on bed, getting up from sitting or from bed, shopping, 
TABLE 4: Reliability and confirmatory factor analysis of the Malay version OAKHQOL.

\begin{tabular}{|c|c|c|c|c|c|}
\hline Construct & Item & Factor loading & Cronbach alpha & CR & AVE \\
\hline \multirow{10}{*}{ Physical activity } & pyl & 0.774 & \multirow{10}{*}{0.933} & \multirow{10}{*}{0.915} & \multirow{10}{*}{0.743} \\
\hline & py 2 & 0.736 & & & \\
\hline & py 4 & 0.653 & & & \\
\hline & py5 & 0.646 & & & \\
\hline & py6 & 0.672 & & & \\
\hline & py7 & 0.771 & & & \\
\hline & py8 & 0.716 & & & \\
\hline & py10 & 0.804 & & & \\
\hline & pyl1 & 0.679 & & & \\
\hline & py 28 & 0.742 & & & \\
\hline \multirow{8}{*}{ Mental } & $\mathrm{m} 15$ & 0.773 & \multirow{8}{*}{0.919} & \multirow{8}{*}{0.921} & \multirow{8}{*}{0.796} \\
\hline & $\mathrm{m} 17$ & 0.754 & & & \\
\hline & $\mathrm{m} 18$ & 0.726 & & & \\
\hline & $\mathrm{m} 19$ & 0.899 & & & \\
\hline & $\mathrm{m} 20$ & 0.910 & & & \\
\hline & $\mathrm{m} 21$ & 0.798 & & & \\
\hline & $\mathrm{m} 35$ & 0.656 & & & \\
\hline & $\mathrm{m} 41$ & 0.608 & & & \\
\hline \multirow{3}{*}{ Social functioning } & sf30 & 0.756 & \multirow{3}{*}{0.865} & \multirow{3}{*}{0.867} & \multirow{3}{*}{0.867} \\
\hline & sf31 & 0.851 & & & \\
\hline & sf32 & 0.871 & & & \\
\hline \multirow{3}{*}{ Social support } & $\mathrm{sp} 40$ & 0.786 & \multirow{3}{*}{0.888} & \multirow{3}{*}{0.890} & \multirow{3}{*}{0.686} \\
\hline & $\mathrm{sp} 42$ & 0.871 & & & \\
\hline & sp43 & 0.901 & & & \\
\hline \multirow{4}{*}{ Pain } & pn34 & 0.538 & \multirow{4}{*}{0.809} & \multirow{4}{*}{0.819} & \multirow{4}{*}{0.540} \\
\hline & pn33 & 0.657 & & & \\
\hline & pn27 & 0.834 & & & \\
\hline & pn26 & 0.847 & & & \\
\hline
\end{tabular}

CR: construct reliability; AVE: average variance extracted.

TABLE 5: Pearson correlation coefficient.

\begin{tabular}{llr}
\hline & $r$ & $p$ value \\
\hline Physical activity domain OAKHQOL and functional domain WOMAC & 0.72 & $<0.001$ \\
Pain domain WOMAC and pain domain OAKHQOL & 0.55 & $<0.001$ \\
\hline
\end{tabular}

Correlation is significant at the 0.05 level (2-tailed).

and also doing house chores [16]. Perhaps future research can examine the criterion validity for the mental construct, social functioning, and social support of the Malay version of OAKHQOL. The SF36 is one questionnaire that has been used to assess health-related QOL for people with knee $\mathrm{OA}$, although it is not disease-specific. This questionnaire has been validated in the Malay language. We suggest correlating the OAKHQOL scores with the SF36 in a future study.

For the known group validity, we found that the Malay version of OAKHQOL discriminates well for the BMI groups and the severity of disease based on plain radiograph for the physical activity, pain, and mental domains. However, for the social domains, it was not discriminative based on disease severity. This finding was similar to the findings of De Tejada et al., who conducted the validation study in Spanish [2]. Both Malay and English versions after validation are shown in Tables 9 and 10.

This study is not without limitation. First, this study involved only people with knee OA; therefore, the findings may not be generalized to patients with hip OA. In addition, the convenient sampling was applied. Thus, it may not represent the true knee OA population in the community. It is also good to measure the responsiveness of this questionnaire 


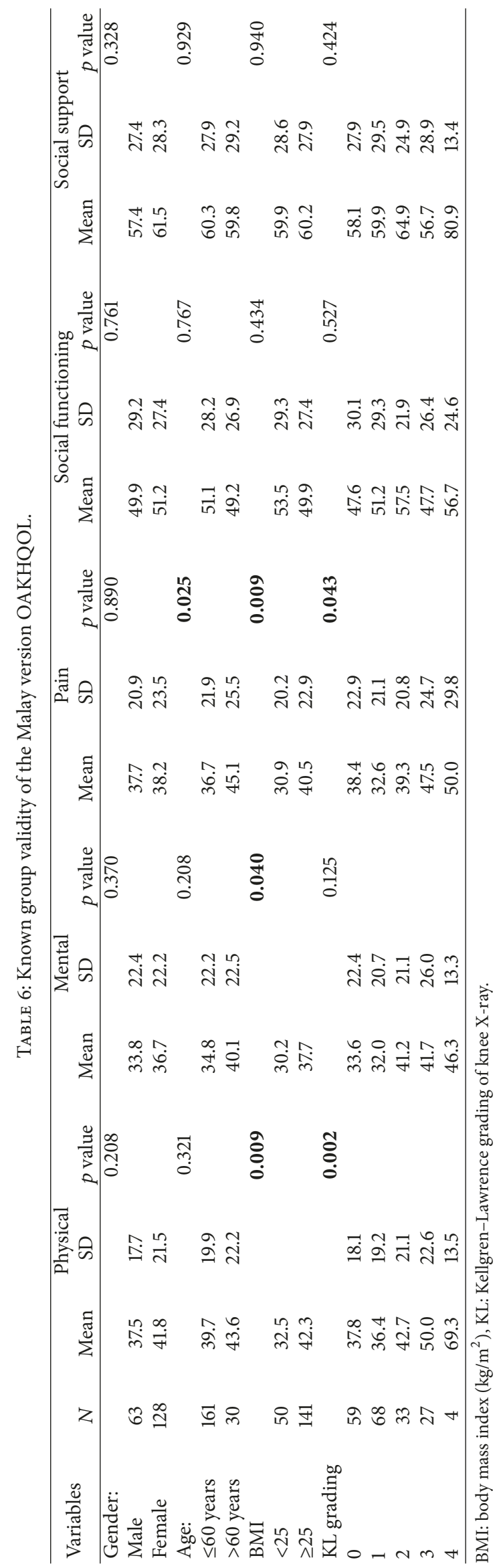


TABLE 7: Prevalidation of Malay version of OAKHQOL questionnaire (40 items).

\begin{tabular}{|c|c|c|}
\hline & & Domain \\
\hline 1 & Saya mengalami kesusahan untuk berjalan & pyl \\
\hline 2 & $\begin{array}{c}\text { Saya mengalami kesusahan untuk tunduk atau meluruskan } \\
\text { badan/bangun semula }\end{array}$ & py2 \\
\hline 3 & Saya mengalami kesusahan untuk membawa barang yang berat & py3 \\
\hline 4 & Saya mengalami kesusahan untuk menuruni tangga & py4 \\
\hline 5 & Saya mengalami kesusahan untuk menaiki tangga & py5 \\
\hline 6 & Saya mengalami kesusahan untuk mandi & py6 \\
\hline 7 & $\begin{array}{l}\text { Saya mengalami kesusahan untuk berpakaian lengkap (seperti } \\
\text { memakai stoking, kasut, seluar dan sebagainya) }\end{array}$ & py7 \\
\hline 8 & Saya mengalami kesusahan untuk memotong kuku kaki & py8 \\
\hline 9 & $\begin{array}{l}\text { Saya mengalami kesusahan untuk bergerak selepas lama berada } \\
\text { dalam kedudukan yang sama }\end{array}$ & py9 \\
\hline 10 & Saya mengalami kesusahan untuk masuk dan keluar daripada kereta & py10 \\
\hline 11 & $\begin{array}{l}\text { Saya mengalami kesusahan untuk menggunakan kenderaan awam } \\
\text { (bas, teksi dsb) }\end{array}$ & pyll \\
\hline 12 & Saya perlukan masa untuk bersendiri/saya perlu bersendiri & pyl3 \\
\hline 13 & $\begin{array}{c}\text { Saya memerlukan masa yang lebih lama untuk melakukan sesuatu } \\
\text { perkara }\end{array}$ & py14 \\
\hline 14 & Saya kurang bersemangat disebabkan sakit & $\mathrm{m} 15$ \\
\hline 15 & Saya risau jika saya perlu bergantung kepada orang lain & $\mathrm{m} 16$ \\
\hline 16 & Saya risau menjadi tidak berkemampuan & $\mathrm{m} 17$ \\
\hline 17 & Saya merasa malu apabila orang melihat saya & $\mathrm{m} 18$ \\
\hline 18 & Saya berasa gelisah & $\mathrm{m} 19$ \\
\hline 19 & Saya berasa tertekan & $\mathrm{m} 20$ \\
\hline 20 & Saya merasakan kehidupan keluarga saya terjejas & $\mathrm{m} 21$ \\
\hline 21 & $\begin{array}{l}\text { Saya mengalami kesusahan untuk berada dikedudukan yang sama } \\
\text { untuk jangkamasa yang lama (duduk, berdiri, tidak bergerak dsb) }\end{array}$ & py24 \\
\hline 22 & Saya memerlukan tongkat atau alat bantu untuk berjalan & py 25 \\
\hline 23 & Saya mengalami kesakitan (kekerapan) & pn26 \\
\hline 24 & Saya mengalami kesakitan (keterukan) & pn27 \\
\hline 25 & $\begin{array}{l}\text { Saya memerlukan pertolongan untuk membuat sesuatu seperti kerja } \\
\text { rumah dan membeli belah }\end{array}$ & py 28 \\
\hline 26 & Saya rasa lebih tua daripada umur saya & $\mathrm{m} 29$ \\
\hline 27 & $\begin{array}{l}\text { Saya mampu/boleh merancang projek/program untuk jangkamasa } \\
\text { yang panjang }\end{array}$ & sf30 \\
\hline 28 & Saya keluar rumah sekerap mana yang saya suka & sf31 \\
\hline 29 & Saya melayan tetamu di rumah sebanyak mana yang saya suka & sf32 \\
\hline 30 & Saya mengalami kesukaran untuk tidur atau tidur semula kerana sakit & pn33 \\
\hline 31 & Saya terjaga disebabkan sakit & pn34 \\
\hline 32 & Saya tertanya-tanya apa yang bakal berlaku/kan terjadi kepada saya & $\mathrm{m} 35$ \\
\hline 33 & Saya pemarah/mudah marah atau agresif & $\mathrm{m} 36$ \\
\hline 34 & Saya rasa saya menyakiti hati mereka yang rapat dengan saya & m37 \\
\hline 35 & Saya merasa risau tentang kesan sampingan rawatan saya & $\mathrm{m} 38$ \\
\hline 36 & $\begin{array}{c}\text { Saya boleh berkongsi dengan orang lain tentang kesukaran yang saya } \\
\text { alami disebabkan penyakit sendi (arthritis) sebanyak mana yang saya } \\
\text { suka }\end{array}$ & $\operatorname{sp} 39$ \\
\hline 37 & $\begin{array}{l}\text { Saya merasakan orang lain faham tentang kesusahan yang saya alami } \\
\text { disebabkan penyakit sendi (arthritis) saya }\end{array}$ & sp40 \\
\hline 38 & Saya merasa malu untuk meminta bantuan/pertolongan jika perlu & $\mathrm{m} 41$ \\
\hline 39 & $\begin{array}{l}\text { Saya rasa saya diberi sokongan oleh orang yang rapat dengan saya } \\
\text { (pasangan dan keluarga) }\end{array}$ & $\mathrm{sp} 42$ \\
\hline 40 & $\begin{array}{l}\text { Saya rasa saya diberi sokongan oleh orang yang berada di sekeliling } \\
\text { saya (kawan dan jiran) }\end{array}$ & sp43 \\
\hline
\end{tabular}

Py: physical activity; m: mental; pn: pain; sf: social functioning; sp: social support. 
TABLE 8: Prevalidation of English version of OAKHQOL questionnaire (40 items).

\begin{tabular}{|c|c|c|}
\hline & & Domain \\
\hline 1 & I have difficulty walking & pyl \\
\hline 2 & I have difficulty bending down or straightening up & py2 \\
\hline 3 & I have difficulty carrying heavy things & py3 \\
\hline 4 & I have difficulty going down stairs & py 4 \\
\hline 5 & I have difficulty climbing stairs & py5 \\
\hline 6 & I have difficulty taking a bath & py6 \\
\hline 7 & I have difficulty getting dressed & py7 \\
\hline 8 & I have difficulty cutting my toe-nails & py8 \\
\hline 9 & I have difficulty getting going again after staying in the same position for a long time & py9 \\
\hline 10 & I have difficulty getting in and out of a car & py10 \\
\hline 11 & I have difficulty using public transport & pyl1 \\
\hline 12 & I have to pace myself & py13 \\
\hline 13 & I take more time to do things & py14 \\
\hline 14 & My spirits are low because of the pain & $\mathrm{m} 15$ \\
\hline 15 & I worry about being dependent on others & $\mathrm{m} 16$ \\
\hline 16 & I worry about being disabled & $\mathrm{m} 17$ \\
\hline 17 & I feel embarrassed when people look at me & $\mathrm{m} 18$ \\
\hline 18 & I am anxious & $\mathrm{m} 19$ \\
\hline 19 & I am depressed & $\mathrm{m} 20$ \\
\hline 20 & I feel my family life is being affected & $\mathrm{m} 21$ \\
\hline 21 & I have difficulty staying in the same position for a long time & py 24 \\
\hline 22 & I need a walking stick/cane or crutches to walk & py 25 \\
\hline 23 & I have pain (describe frequency) & pn26 \\
\hline 24 & I have pain (describe intensity) & pn27 \\
\hline 25 & I need help for things like housework and shopping & py 28 \\
\hline 26 & I feel older than my age & $\mathrm{m} 29$ \\
\hline 27 & I am able to plan projects for the long term & sf30 \\
\hline 28 & I get out of the house as much as I like & sf31 \\
\hline 29 & I entertain at home as much as I like & sf32 \\
\hline 30 & I have difficulty getting to sleep or getting back to sleep because of pain & pn33 \\
\hline 31 & I wake up because of pain & pn34 \\
\hline 32 & I wonder what will become of me & m35 \\
\hline 33 & I am irritable or aggressive & $\mathrm{m} 36$ \\
\hline 34 & I feel I annoy those close to me & $\mathrm{m} 37$ \\
\hline 35 & I am worried about the side effects of my treatment & $\mathrm{m} 38$ \\
\hline 36 & I can talk to others about the difficulties I have due to my arthritis as much as I like & $\operatorname{sp} 39$ \\
\hline 37 & I feel others understand the difficulties I have because of my arthritis & $\mathrm{sp} 40$ \\
\hline 38 & I am embarrassed to ask for help if I need it & $\mathrm{m} 41$ \\
\hline 39 & I feel supported by people close to me & $\mathrm{sp} 42$ \\
\hline 40 & I feel supported by those around me & sp43 \\
\hline
\end{tabular}

Py: physical activity; m: mental; pn: pain; sf: social functioning; sp: social support.

in a clinical trial where it can be used to evaluate changes in patient status following therapeutic intervention.

\section{Conclusion}

The Malay version of OAKHQOL consisting of five factors assessed through 28 items was valid, reliable, and acceptable to measure quality of life in Malaysian population with knee OA.

\section{Ethical Approval}

This study protocol was approved by the Research Ethics Committee (Human), School of Medical Sciences, Universiti 
TABLE 9: Postvalidation of English version of OAKHQOL questionnaire (28 items).

\begin{tabular}{|c|c|c|}
\hline & & Domain \\
\hline 1 & I have difficulty walking & pyl \\
\hline 2 & I have difficulty bending down or straightening up & py2 \\
\hline 3 & I have difficulty going down stairs & py4 \\
\hline 4 & I have difficulty climbing stairs & py5 \\
\hline 5 & I have difficulty taking a bath & py6 \\
\hline 6 & I have difficulty getting dressed & py7 \\
\hline 7 & I have difficulty cutting my toe-nails & py8 \\
\hline 8 & I have difficulty getting in and out of a car & py10 \\
\hline 9 & I have difficulty using public transport & pyll \\
\hline 10 & My spirits are low because of the pain & $\mathrm{m} 15$ \\
\hline 11 & I worry about being disabled & $\mathrm{m} 17$ \\
\hline 12 & I feel embarrassed when people look at me & $\mathrm{m} 18$ \\
\hline 13 & I am anxious & $\mathrm{m} 19$ \\
\hline 14 & I am depressed & $\mathrm{m} 20$ \\
\hline 15 & I feel my family life is being affected & $\mathrm{m} 21$ \\
\hline 16 & I have pain (describe frequency) & pn26 \\
\hline 17 & I have pain (describe intensity) & pn27 \\
\hline 18 & I need help for things like housework and shopping & py 28 \\
\hline 19 & I am able to plan projects for the long term & sf 30 \\
\hline 20 & I get out of the house as much as I like & sf31 \\
\hline 21 & I entertain at home as much as I like & sf32 \\
\hline 22 & I have difficulty getting to sleep or getting back to sleep because of pain & pn33 \\
\hline 23 & I wake up because of pain & pn34 \\
\hline 24 & I wonder what will become of me & $\mathrm{m} 35$ \\
\hline 25 & I feel others understand the difficulties I have because of my arthritis & sp40 \\
\hline 26 & I am embarrassed to ask for help if I need it & $\mathrm{m} 41$ \\
\hline 27 & I feel supported by people close to me & $\mathrm{sp} 42$ \\
\hline 28 & I feel supported by those around me & $\mathrm{sp} 43$ \\
\hline
\end{tabular}

Py: physical activity; m: mental; pn: pain; sf: social functioning; sp: social support.

TABLE 10: Postvalidation of Malay version of OAKHQOL questionnaire (28 items).

\begin{tabular}{|c|c|c|}
\hline & & Domain \\
\hline 1 & Saya mengalami kesusahan untuk berjalan & pyl \\
\hline 2 & Saya mengalami kesusahan untuk tunduk atau meluruskan badan/bangun semula & py2 \\
\hline 3 & Saya mengalami kesusahan untuk menuruni tangga & py 4 \\
\hline 4 & Saya mengalami kesusahan untuk menaiki tangga & py5 \\
\hline 5 & Saya mengalami kesusahan untuk mandi & py6 \\
\hline 6 & Saya mengalami kesusahan untuk berpakaian lengkap (seperti memakai stoking, kasut, seluar dan sebagainya) & py7 \\
\hline 7 & Saya mengalami kesusahan untuk memotong kuku kaki & py8 \\
\hline 8 & Saya mengalami kesusahan untuk masuk dan keluar daripada kereta & py10 \\
\hline 9 & Saya mengalami kesusahan untuk menggunakan kenderaan awam (bas, teksi dsb) & pyl1 \\
\hline 10 & Saya kurang bersemangat disebabkan sakit & m15 \\
\hline 11 & Saya risau menjadi tidak berkemampuan & $\mathrm{m} 17$ \\
\hline 12 & Saya merasa malu apabila orang melihat saya & $\mathrm{m} 18$ \\
\hline 13 & Saya berasa gelisah & m19 \\
\hline 14 & Saya berasa tertekan & $\mathrm{m} 20$ \\
\hline 15 & Saya merasakan kehidupan keluarga saya terjejas & $\mathrm{m} 21$ \\
\hline 16 & Saya mengalami kesakitan (kekerapan) & pn26 \\
\hline 17 & Saya mengalami kesakitan (keterukan) & pn27 \\
\hline 18 & Saya memerlukan pertolongan untuk membuat sesuatu seperti kerja rumah dan membeli belah & py 28 \\
\hline 19 & Saya mampu/boleh merancang projek/program untuk jangkamasa yang panjang & sf30 \\
\hline 20 & Saya keluar rumah sekerap mana yang saya suka & sf31 \\
\hline 21 & Saya melayan tetamu di rumah sebanyak mana yang saya suka & sf32 \\
\hline 22 & Saya mengalami kesukaran untuk tidur atau tidur semula kerana sakit & pn33 \\
\hline 23 & Saya terjaga disebabkan sakit & pn34 \\
\hline 24 & Saya tertanya-tanya apa yang bakal berlaku/kan terjadi kepada saya & m35 \\
\hline 25 & Saya merasakan orang lain faham tentang kesusahan yang saya alami disebabkan penyakit sendi (arthritis) saya & $\mathrm{sp} 40$ \\
\hline 26 & Saya merasa malu untuk meminta bantuan/pertolongan jika perlu & $\mathrm{m} 41$ \\
\hline 27 & Saya rasa saya diberi sokongan oleh orang yang rapat dengan saya (pasangan dan keluarga) & sp42 \\
\hline 28 & Saya rasa saya diberi sokongan oleh orang yang berada di sekeliling saya (kawan dan jiran) & sp43 \\
\hline
\end{tabular}

Py: physical activity; m: mental; pn: pain; sf: social functioning; sp: social support. 
Sains Malaysia (FWA Reg. no. 00007718; IRB Reg. no. 00004494) and procedures followed were in accordance with the Helsinki Declaration of 1975.

\section{Consent}

The participants involved in the study have signed consent form to participate in the study.

\section{Disclosure}

An earlier version of this work was presented as a poster at the Medical Journal of Malaysia in 4th Asia Pacific Conference on Public Health.

\section{Conflicts of Interest}

The authors declare that there are no conflicts of interest regarding the publication of this article.

\section{Acknowledgments}

The authors would like to acknowledge the Universiti Sains Malaysia for the Grant (1001/PPSP/812132) to conduct this study. They also gratefully acknowledge the cooperation of all participating subjects and staff involved in this project. The authors would like to acknowledge the questionnaire's author Anne-Christine Rat for giving them permission to use the OAKHQOL as well as a copy of the original English version.

\section{References}

[1] D. T. Felson, "Epidemiology of hip and knee osteoarthritis," Epidemiologic Reviews, vol. 10, pp. 1-28, 1988.

[2] M. G. S. De Tejada et al., "Adaptation and validation of the Osteoarthritis Knee and Hip Quality of Life (OAKHQOL) questionnaire for use in patients with osteoarthritis in Spain," Clinical Rheumatology, vol. 30, no. 12, pp. 1563-1575, 2011.

[3] H. M. Lapsley et al., "Living with osteoarthritis: patient expenditures, health status, and social impact," Arthritis Care \& Research, vol. 45, no. 3, pp. 301-306, 2001.

[4] R. F. Meenan, J. H. Mason, J. J. Anderson, A. A. Guccione, and L. E. Kazis, "AIMS2. The content and properties of a revised and expanded arthritis impact measurement scales health status questionnaire," Arthritis \& Rheumatology, vol. 35, no. 1, pp. 1-10, 1992.

[5] S. G. Parker, S. M. Peet, C. Jagger, M. Farhan, and C. M. Castleden, "Measuring health status in older patients. The SF36 in practice," Age and Ageing, vol. 27, no. 1, pp. 13-18, 1998.

[6] N. Bellamy, W. W. Buchanan, C. H. Goldsmith, J. Campbell, and L. W. Stitt, "Validation study of WOMAC: a health status instrument for measuring clinically important patient relevant outcomes to antirheumatic drug therapy in patients with osteoarthritis of the hip or knee," The Journal of Rheumatology, vol. 15, no. 12, pp. 1833-1840, 1988.

[7] M. Lequesne et al., "Indexes of severity for osteoarthritis of the hip and knee: validation-value in comparison with other assessment tests," Scandinavian Journal of Rheumatology, vol. 16, suppl 65, pp. 85-89, 1987.
[8] G. Hawker et al., "Comparison of a generic (SF-36) and a disease specific (WOMAC)(Western Ontario and McMaster Universities Osteoarthritis Index) instrument in the measurement of outcomes after knee replacement surgery," The Journal of Rheumatology, vol. 22, no. 6, pp. 1193-1196, 1995.

[9] M. M. Zulkifli et al., "Psychometric properties of the malay language version of knee injury and osteoarthritis outcome score (Koos) questionnaire among knee osteoarthritis patients: a confirmatory factor analysis," Malaysian Orthopaedic Journal, vol. 11, no. 2, pp. 7-14, 2017.

[10] A.-C. Rat, J. Coste, J. Pouchot et al., "OAKHQOL: A new instrument to measure quality of life in knee and hip osteoarthritis," Journal of Clinical Epidemiology, vol. 58, no. 1, pp. 47-55, 2005.

[11] C. D. Stapleton, Basic Concepts and Procedures of Confirmatory Factor Analysis, 1997.

[12] T. Brown, Confirmatory Factor Analysis for Applied Research, Guilford, New York, NY, USA, 2006.

[13] M. W. Browne and R. Cudeck, Alternative Ways of Assessing Model Fit, K. A. Bollen and J. S. Long, Eds., 1993.

[14] J. F. Hair, Multivariate Data Analysis: A Global Perspective, vol. 7, Pearson, Upper Saddle River, NJ, USA, 2010.

[15] A.-C. Rat, J. Pouchot, J. Coste et al., "Development and testing of a specific quality-of-life questionnaire for knee and hip osteoarthritis: OAKHQOL (OsteoArthritis of Knee Hip Quality Of Life)," Joint Bone Spine, vol. 73, no. 6, pp. 697-704, 2006.

[16] N. Bellamy, WOMAC osteoarthritis index 3.1 User guide XI, 2015.

[17] N. Bellamy, G. Wells, and J. Campbell, "Relationship between severity and clinical importance of symptoms in osteoarthritis," Clinical Rheumatology, vol. 10, no. 2, pp. 138-143, 1991.

[18] O. Ethgen, O. Bruyerè, F. Richy, C. Dardennes, and J.-Y. Reginster, "Health-related quality of life in total hip and total knee arthroplasty," The Journal of Bone \& Joint Surgery, vol. 86, no. 5, pp. 963-974, 2004.

[19] A. Zainudin, Structural Equation Modeling Using AMOS Graphic, Shah Alam: Universiti Teknologi MARA Publication Centre (UPENA), 2012.

[20] M. S. Garver and J. T. Mentzer, "Logistics research methods: employing structural equation modeling to test for construct validity," Journal of Business Logistics, vol. 20, no. 1, p. 33, 1999.

[21] D. Gefen, D. W. Straub, and E. E. Rigdon, "An update and extension to SEM guidelines for admnistrative and social science research," Management Information Systems Quarterly, vol. 35, no. 2, pp. iii-xiv, 2011.

[22] R. van de Schoot, P. Lugtig, and J. Hox, "A checklist for testing measurement invariance," European Journal of Developmental Psychology, vol. 9, no. 4, pp. 486-492, 2012.

[23] J. B. Schreiber, F. K. Stage, J. King, A. Nora, and E. A. Barlow, "Reporting structural equation modeling and confirmatory factor analysis results: a review," The Journal of Educational Research, vol. 99, no. 6, pp. 323-337, 2006.

[24] J. F. Hair, W. C. Black, and B. J. Babin, Multivariate Data Analysis, 6. Baskı, Pearson (Prentice Hall), Upper Saddle River, NJ, USA, 2005.

[25] D. C. Hambrick, S. Finkelstein, T. S. Cho, and E. M. Jackson, "Isomorphism in reverse: institutional theory as an explanation for recent increases in intraindustry heterogeneity and managerial discretion," Research in Organizational Behavior, vol. 26, pp. 307-350, 2006.

[26] D. L. Streiner, G. R. Norman, and J. Cairney, Health Measurement Scales: A Practical Guide to Their Development and Use, Oxford University Press, USA, 2015. 
[27] M. Davidson, "Known-groups validity," in Encyclopedia of Quality of Life and Well-Being Research, pp. 3481-3482, Springer, 2014.

[28] M. Mafauzy, "The problems and challenges of the aging population of malaysia," The Malaysian Journal of Medical Sciences, vol. 7, no. 1, pp. 1-3, 2000.

[29] M. Saffari, M. K. Emami Meybodi, H. G. Koenig, A. H. Pakpour, and H. Rshidi Jahan, "Psychometric examination of the Persian version of Osteoarthritis Knee and Hip Quality of Life questionnaire," International Journal of Rheumatic Diseases, vol. 20, no. 11, pp. 1648-1657, 2017.

[30] B. M. Byrne, Structural Equation Modeling with EQS: Basic Concepts, Applications, And Programming, Routledge, 2013.

[31] J. P. Stevens, Applied Multivariate Statistics for The Social Sciences, Routledge, 2012.

[32] D. D. Suhr, Exploratory or Confirmatory Factor Analysis? SAS Institute Cary, 2006. 


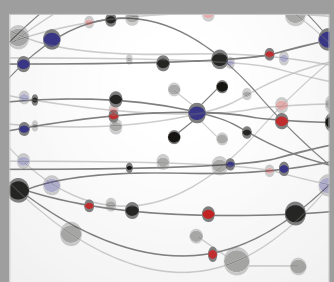

The Scientific World Journal
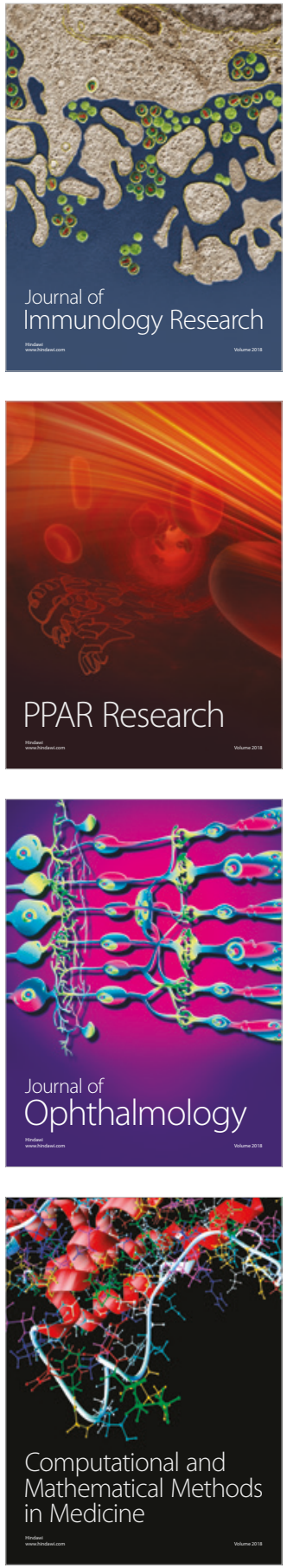

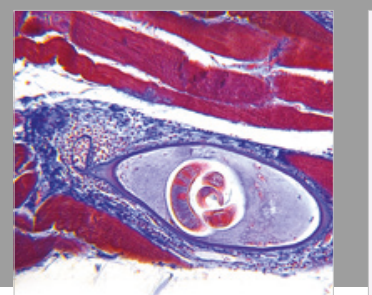

Gastroenterology Research and Practice

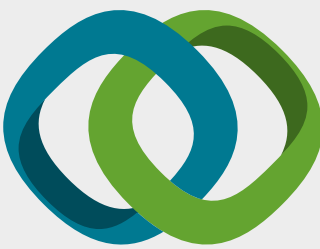

\section{Hindawi}

Submit your manuscripts at

www.hindawi.com
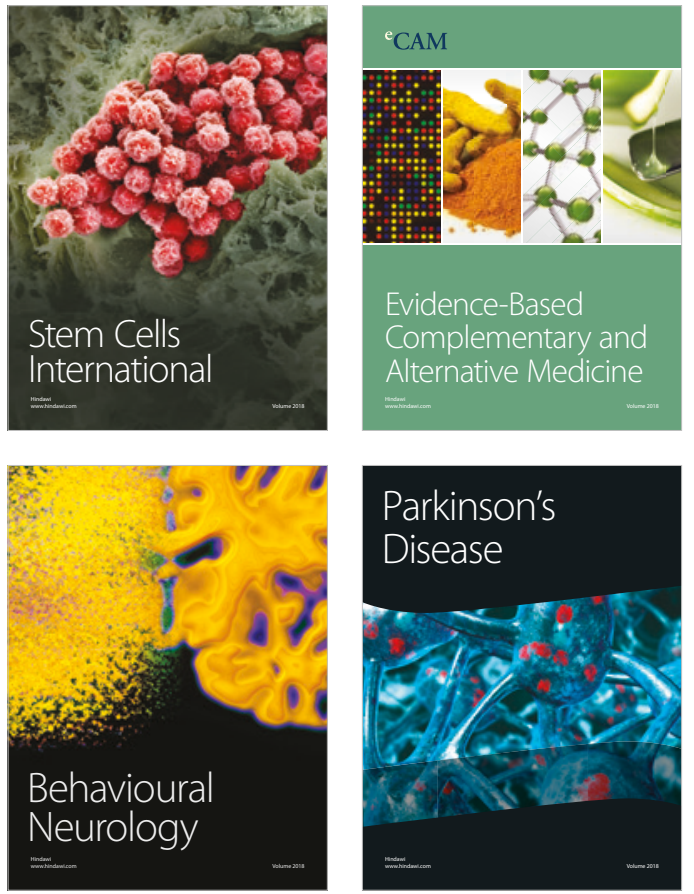

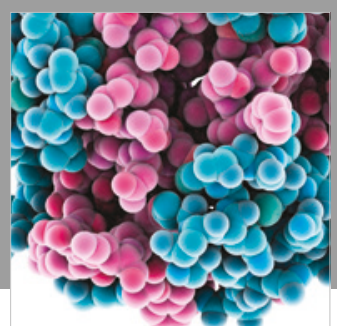

ournal of

Diabetes Research

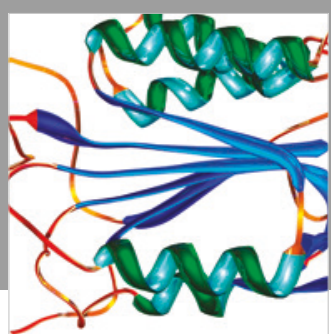

Disease Markers
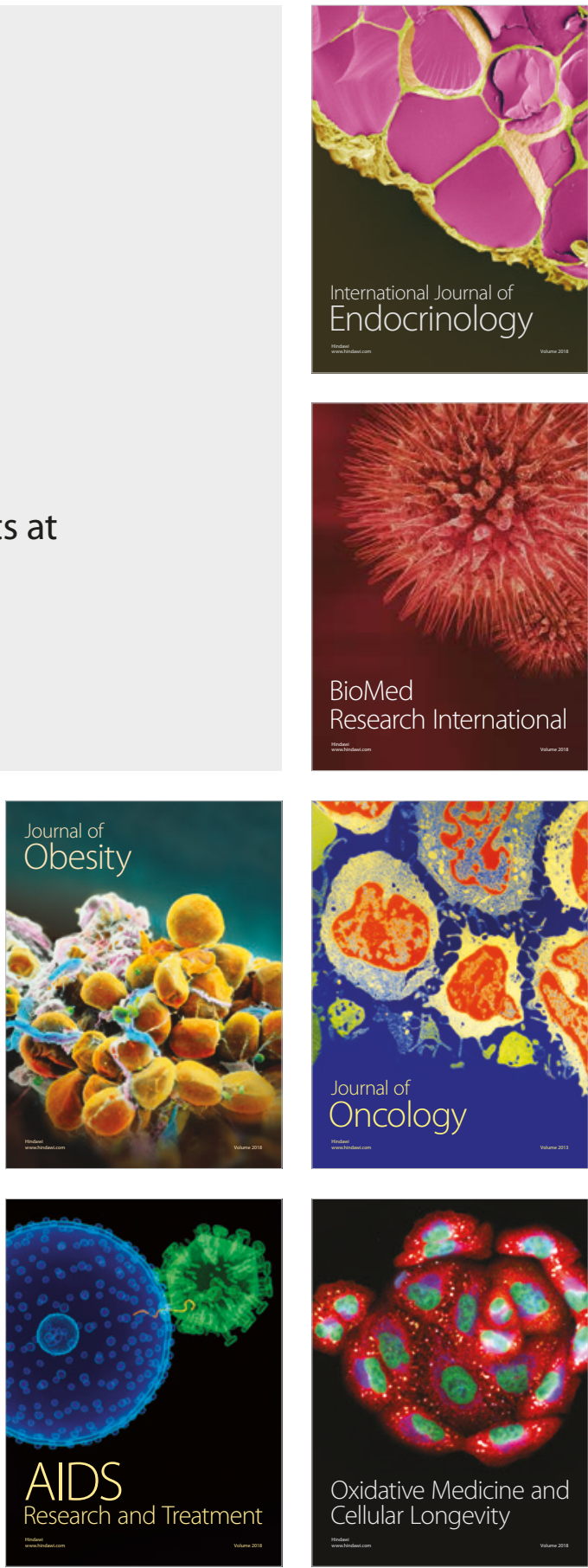